\title{
Effects of Factor Price Distortion on Industrial Environmental Efficiency: Evidence from Environmental Pollution in China
}

\author{
Xiangxiang Sun ${ }^{1}$, Zhangwang Chen ${ }^{1 *}$, Liangxiong Huang ${ }^{2}$ \\ ${ }^{1}$ School of Economics and Management, Fuzhou University, Fuzhou, China \\ ${ }^{2}$ School of Economics and Commerce, South China University of Technology, Panyu District, Guangzhou, China
}

Received: 11 September 2019

Accepted: 4 January 2020

\begin{abstract}
This study integrates factor price distortion, industrial structure upgrading and industrial environmental efficiency into an analytical framework and identifies the relationship between factor price distortion and industrial environmental efficiency using the fixed effect model. Meanwhile, we also examine the influence mechanism of industrial structure upgrading on the factor price distortion affecting industrial environmental efficiency. The results indicate that factor price distortion significantly inhibits industrial environmental efficiency. Moreover, we analyze the interaction between factor price distortion and industrial structure upgrading and find that the inhibitory effect of factor price distortion on industrial environmental efficiency is weakened in areas with better upgrading of industrial structure. Further investigation of the heterogeneity effect shows that the negative effect of factor price distortion on industrial environmental efficiency is more significant in the central and western regions. The government should improve the distortion of factor price and optimize the industrial structure so as to promote the green development of industrial industry.
\end{abstract}

Keywords: factor price distortion, industrial environmental efficiency, industrial structure upgrading, fixed effect model

\section{Introduction}

With the rapid advancement of industrialization and urbanization, China has become the largest energy consumer in the world, as well as a major producer of greenhouse gases and atmospheric pollutants. The industrial sector is not only an important driving

*e-mail: 05919833@163.com force for economic development, but also the largest sector of resource consumption and pollution emission. The industrial added value accounting for $40.1 \%$ of the country consumes $68 \%$ of the energy and produces $83 \%$ of the carbon dioxide during the period of reform and opening up [1]. The excessive consumption of resources and deterioration of environmental quality caused by industrial development have become obstacles to sustainable development in China. The goal of sustainable development is to improve environmental efficiency and reduce pollution 
[2]. Industrial environmental efficiency refers to the impact of economic value created by industrial sectors on the environment, aiming at analyzing the coordination between industrial development and environmental impact. Therefore, it is worth further identifying the influencing factors of industrial environmental efficiency, which has reference value for improving green development and reducing pollution emissions.

Most of the studies on the influencing factors of environmental efficiency focus on technological progress, environmental regulation, and foreign direct investment and export [3-6]. However, factor price distortion, as an important factor affecting production cost and technology input, has not received enough attention. The serious factor market distortion in China has been confirmed by a large number of studies [79]. Compared with the product market, the distortion of factor price is serious, which is determined by administrative power and government regulation. Factor price distortion reduces the efficiency of resource allocation and productivity [8]. On the one hand, factor price distortion fails to demonstrate the scarcity of productive factor. On the other hand, relatively low factor prices provide profits relying on low factor input cost [10] and high polluted resources. Therefore, we believe that factor price distortion will inevitably affect industrial environmental efficiency, which deserves further discussion.

Factor price distortion, characterized by price distortions and factor misallocation, has an impact not only on industrial structure, but also on industrial environmental efficiency. Based on the research framework, our study discusses the impact of factor price distortion on industrial environmental efficiency and analyzes the influence mechanism of industrial structure upgrading in factor price distortion affecting industrial environmental efficiency. We further investigate the heterogeneous effect of factor price distortion on industrial environmental efficiency.

Based on the above research framework, our study's main contribution can be highlighted as follows. First, there are few studies of the impact of factor price distortions on industrial environmental efficiency. The study considers the industrial environmental efficiency based on super-SBM method as dependent variable and uses the fixed effect model to identify the relationship between factor price distortion and industrial environmental efficiency. This study fills the gap of industrial environmental efficiency base on market distortion. Second, the study on the relationship between factor price distortion and industrial environmental efficiency from the perspective of industrial structure upgrading is also rare. Our study examines the influence mechanism of industrial structure upgrading on the factor price distortion affecting industrial environmental efficiency. Third, our study also analyzes the heterogeneous effect of factor price distortion in different economic development conditions. In general, our study fills the academic gap to analyze the industrial environmental efficiency from the perspective of market distortions and expands the empirical framework by discussing the structural transformation.

The rest of the study is organized as follows: Section 2 introduces the literature review. Section 3 analyzes the methods, variable measurement and data. Section 4 discusses and summarizes the empirical results. Section 5 puts forward research conclusions.

\section{Literature Review}

Based on the above research topic, the literature reviews are discussed from the following aspects. Firstly, we discuss the environmental impact of factor price distortion. Secondly, we analyze the impact of industrial structure upgrading on the environment. Finally, we summarize the relationship between factor market distortion and structure upgrading.

Labor force, capital, energy and other factors are important driving forces for economic growth. However, the gradual reform of the factor market has led to the lag of the development of factor market behind product market in China. The government uses administrative monopoly power to intervene in the pricing mechanism of the factor market [11], which causes serious factor price distortion in different ownerships enterprises and different sectors and areas [9]. Huang and Tao [12] observe that the factor market distortion is formed and the price of factors of production is depressed. Government officials artificially depress factor prices by intervening and controlling factor markets in order to promote economic growth [13-14].

Based on the impact of factor price distortion on the environment, Lin and Chen [10] find that factor market distortion affected by government intervention hinders the promotion of green total factor productivity. Yin et al. [7] empirically prove that factor price distortion increases electricity consumption in industrial enterprises. Dai and Cheng [15] find that there are market distortions in the energy sector, such as subsidies and price regulations. Energy prices are tightly regulated and underestimated to reduce the energy costs, and industrial enterprises benefit greatly from subsidies that further increase energy consumption [16]. Technological innovation can reduce energy consumption and pollution emissions, which has been confirmed in many studies [18-19]. The distorted financing structure and high financing cost in factor market are not conducive to the $R \& D$ investment and hinder technological innovation [20-22]. Factor price is an effective signal. As it rises, producers will improve efficiency by shifting to alternative factors [23]. It may also trigger energy-saving technological innovation to save costs and reduce pollution emissions [24]. Therefore, factor price distortion stimulates the 
production activities, promotes the overuse of highly polluted resources, reduces willingness to invest in R\&D and ultimately affects industrial environmental efficiency.

Industrial structure and technology progress affect the environment [25]. Many studies argue that the secondary industry is the main sector of carbon dioxide emissions [26-27]. Li et al. [28] and Hao et al. [29] analyze the convergence of carbon intensity using the panel model and suggest that secondary industry is negatively correlated with carbon intensity. $\mathrm{Xu}$ and Jiang [30] and Shi [31] also conclude that industrial structure has an impact on energy intensity and energy efficiency. Zhou et al. [32] discuss the impact of industrial structural transformation and find that technological progress reduces carbon dioxide emissions through upgrading industrial structure. Cheng et al. [33] also propose that the upgrading of industrial structure is negatively correlated with carbon intensity. Fan [34] and Schafer [35] empirically confirm that structural transformation significantly influences energy efficiency. Zhou et al. [36] propose that the transformation of industrial structure promotes the balance between environmental protection and economic development. Therefore, we propose that the transformation of industrial structure inevitably affects the environment.

The underestimation of factor price reduces the production cost of backward production enterprises and subsidizes the investment in the form of excess profits [37]. Factor price distortion keeps the low-end industries profitable, which is not conducive to industrial upgrading and makes a large number of enterprises with high pollution and high energy consumption appear in China. Factor price distortion is not conducive to innovation, and hinders the upgrading of industrial structure [38]. In order to accelerate local economic development, the government attracts a large number of factors to capital-intensive, energy-intensive, heavy chemical industry or low-level processing industry by distorting factor price, which hinders the upgrading of industries to technology-knowledge-intensive industries. Therefore, factor price distortion hinders upgrading and transformation of industrial structure.

\section{Empirical Methodology}

\section{Estimation of Factor Price Distortion}

Serious factor price distortion in China has been confirmed, and is caused by government regulation and administrative power [6-8]. The distortion of factor price shows the deviation between actual factor price and marginal output. The factor price distortion can be divided into absolute distortion of factor price and relative distortion of factor price [39-40]. Production possibilities, frontier technology and production function method are used to evaluate the factor price distortion [7]. The production function method is the most commonly used to measure factor price distortion, which includes the Cobb-Douglas (C-D) production function, transcendental logarithmic production function and time-varying elastic production function [39]. Comparing the C-D production function with the transcendental logarithmic production function, we find that the measurement of C-D production function has a disadvantage of errors in the calculation of marginal output. Therefore, we choose the transcendental logarithmic production function to calculate the factor price distortion.

First, we set the transcendental logarithmic production function according to the input and output factors as follows:

$$
\begin{aligned}
\ln Y_{i t}= & \beta_{0}+\beta_{1} \ln K_{i t}+\beta_{2} \ln L_{i t}+\frac{1}{2} \beta_{3}\left(\ln K_{i t}\right)^{2} . \\
& +\frac{1}{2} \beta_{4}\left(\ln L_{i t}\right)^{2}+\beta_{5} \ln K_{i t} \ln L_{i t}+\varepsilon_{i t}
\end{aligned}
$$

Second, the marginal output of labor and capital factors is further calculated as follows:

$$
\begin{aligned}
& M P_{L, i t}=\left(\beta_{0}+\beta_{4} \ln L_{i t}+\beta_{5} \ln K_{i t}\right) Y_{i t} / L_{i t} \\
& M P_{K, i t}=\left(\beta_{1}+\beta_{3} \ln K_{i t}+\beta_{5} \ln L_{i t}\right) Y_{i t} / K_{i t}
\end{aligned}
$$

Third, this study assumes that the price of labor is $\omega$ and the price of capital is $\gamma$. The absolute distortion of factor price is determined by the ratio of the actual factor price to the marginal output of factor. Specifically:

$$
\begin{aligned}
\operatorname{dist}_{L} & =M P_{L} / \omega \\
\operatorname{dist}_{K} & =M P_{K} / \gamma
\end{aligned}
$$

Formulas (4) and (5) represent the absolute distortion of labor factor and capital factor, respectively.

Fourth, the ratio of absolute distortion of labor factor to absolute distortion of capital factor is relative factor price distortion:

$$
d i s t=\frac{\operatorname{dist}_{K}}{\operatorname{dist}_{L}}=\frac{M P_{K}}{M P_{L}} \cdot \frac{\omega}{\gamma}
$$

...where dist indicates relative distortion of factor price. If dist is greater than 1 , it means that there is a negative distortion of capital relative to labor, and dist less than 1 means that there is a positive distortion of capital relative to labor. 


\section{Calculating Industrial Environmental Efficiency}

This study uses industrial environmental efficiency to examine the balance of industrial economy and environmental impact in different regions. Yang and $\mathrm{Li}$ [41] use the SBM-DEA to measure industrial environmental efficiency. Based on Gomez-Calvet et al. [42], our study selects the Super-SBM model considering the undesirable output to evaluate industrial environmental efficiency. We assume a production system with n DMUs - including the inputs, undesirable outputs and desirable outputs. Each unit (DMU) makes use of $m$ input factors and produces $s_{1}$ desirable output and $s_{2}$ undesirable output. Three vectors are defined: $x \in R^{m}, y^{g} \in R^{S_{1}}$ and $y^{b} \in R^{S_{2}}$, the matrices $X, Y^{g}$ and $Y^{b}$ are defined as follows:

$$
\begin{aligned}
& X=\left[x_{1}, x_{2}, \ldots, x_{L}\right] \in R^{m \times L} \\
& Y^{g}=\left[y_{1}^{g}, y_{2}^{g}, \ldots, y_{L}^{g}\right] \in R^{s_{1} \times L} \\
& Y^{b}=\left[y_{1}^{b}, y_{2}^{b}, \ldots, y_{L}^{b}\right] \in R^{s_{2} \times L}
\end{aligned}
$$

Then, the production possibility set (PPS) is defined as follows:

$$
\begin{gathered}
T=\left\{\left(x, y^{g}, y^{b}\right) \mid x \geq \sum_{j=1}^{L} \lambda_{j} x_{j}, 0 \leq y^{g} \leq \sum_{j=1}^{L} \lambda_{j} y_{j}^{g}, y^{b}\right. \\
\left.\geq \sum_{j=1}^{L} \lambda_{j} y_{j}^{b}, l \leq e \lambda \leq u, \lambda \geq 0\right\}
\end{gathered}
$$

...where $\lambda=\left(\lambda_{1}, \lambda_{2}, \ldots, \lambda_{L}\right)^{\prime} \in R_{+}^{L}$ is a weight vector, $e=(1,1, \ldots, 1) \in R_{+}^{L}$.

Based on tone [43], the SBM model dealing with undesirable outputs is described as follows:

$$
\begin{gathered}
\beta=\min \frac{1-\frac{1}{m} \sum_{i=1}^{m} \frac{s_{i}^{-}}{x_{i 0}}}{1+\frac{1}{s_{1}+s_{2}}\left(\sum_{r=1}^{s_{1}} \frac{s_{r}^{g}}{y_{r 0}^{g}}+\sum_{t=1}^{s_{2}} \frac{s_{t}^{b}}{y_{t 0}^{b}}\right)} \\
\text { s.t. } \quad x_{0}=X \lambda+s^{-} \\
y_{0}^{g}=Y^{g} \lambda-s^{g} \\
y_{0}^{b}=Y^{b} \lambda+s^{b} \\
s^{-} \geq 0, s^{g} \geq 0, s^{b} \geq 0, l \leq e \lambda \leq u, \lambda \geq 0
\end{gathered}
$$

...where the vector $s^{g} \in R_{+}^{S_{1}}$ represents the loss of desirable outputs, $s^{b} \in R_{+}^{S_{2}}$ represents the slacks in undesirable outputs, and $s^{-} \in R_{+}^{m}$ represents the slacks in inputs. The target function value of $\beta$ is solution of the optimization, and its range of value is $0 \leq \beta \leq 1$. If $\beta=1, s^{-}=s^{b}=s^{g}=0$, it indicates that the evaluated decision making the unit is effective.
According to Charnes and Cooper [44], the above formulas are transformed into equivalent linear programming problems.

$$
\begin{gathered}
\beta^{*}=\min \left\{t+\frac{1}{m+s_{2}}\left(\sum_{i=1}^{m} \Upsilon_{i}+\sum_{k=1}^{s_{2}} \Omega_{k}\right)\right. \\
\text { s.t. } \quad 1=t-\frac{1}{s_{1}}\left(\sum_{r=1}^{s_{1}} \Theta_{r}\right) \\
\sum_{j=1, \neq 0}^{L} x_{i j} \Lambda_{j}-x_{i o} \Upsilon_{i}-x_{i 0} t \leq 0,(i=1, \mathrm{~K}, m) \\
\sum_{j=1, \neq 0}^{L} y_{r j}^{g} \Lambda_{j}+y_{r 0}^{g} \Theta_{r}-y_{r 0}^{g} t \geq 0,\left(r=1, \mathrm{~K}, s_{1}\right) \\
\sum_{j=1, \neq 0}^{L} y_{k j}^{b} \Lambda_{j}-y_{k 0}^{b} \Omega_{k}-y_{k 0}^{b} t \geq 0,\left(k=1, \mathrm{~K}, s_{2}\right) \\
\Upsilon_{i} \geq 0\left(\forall_{i}\right), \Theta \geq 0(\forall r), \Omega \geq 0\left(\forall_{k}\right) \\
\Lambda_{j} \geq 0, l t \leq e \Lambda \leq u t, \Lambda \geq 0, t>0
\end{gathered}
$$

...where $\Lambda_{j}=t \lambda, \Upsilon=t \phi, \Theta=t \varphi, \Omega=t \eta$, and $\beta^{*}$ is the environmental efficiency measured by the super-SBM method taking undesirable outputs.

According to Yang and $\mathrm{Li} \mathrm{[41]} \mathrm{and} \mathrm{Li}$ et al. [45], we choose capital, labor, water consumption and energy consumption as input indicators, industrial value added as desirable output indicator, sulfur dioxide emissions, waste water emissions and waste gas emissions as undesirable output indicators.

\section{Empirical Method}

According to the research framework, our study aims to evaluate the impact of factor price distortion on industrial environmental efficiency using the panel data of 29 provinces in China during the period 2007-2015. The regression model is as follows.

efficiency $_{i, t}=\lambda_{0}+\lambda_{1}$ distortion $_{i, t}+X_{i t} T+\alpha_{i}+\varepsilon_{i t}$

...where $i$ represents province and $t$ represents year; efficiency $y_{i, t}$ measures industrial environmental efficiency, which captures the dependent variable; distortion $_{i, t}$ represents the factor price distortion, which captures the independent variable; $X$ and represents the vectors of control variables that also affect industrial environmental efficiency according to the previous studies. Subsequently, we further analyze the interaction between factor price distortion and industrial structure upgrading and establish the model as follows. 
Table 1. Descriptive statistics of main variables.

\begin{tabular}{|c|c|c|c|c|c|}
\hline & $\mathrm{N}$ & Mean & Std Dev & Min & Max \\
\hline Efficiency & 261 & 0.5049 & 0.2017 & 0.1530 & 1.0000 \\
\hline Distortion & 261 & 2.2131 & 1.0570 & 0.1400 & 5.9900 \\
\hline Pgdp & 261 & 10.4294 & 0.5461 & 8.8414 & 11.5895 \\
\hline Urbanization & 261 & 0.5306 & 0.1390 & 0.2800 & 0.9000 \\
\hline Fdi & 261 & 0.3475 & 0.2662 & 0.0108 & 1.2778 \\
\hline R\&d & 261 & 0.1462 & 0.1047 & 0.0284 & 0.6013 \\
\hline Open & 261 & 0.4803 & 0.5757 & 0.0500 & 2.4400 \\
\hline Market & 261 & 5.3879 & 2.7642 & -0.0900 & 18.5800 \\
\hline
\end{tabular}

$$
\begin{gathered}
\text { efficiency }_{i, t}=\lambda_{0}+\lambda_{1} \text { distortion }_{i, t}+\lambda_{2} \text { structure }_{i, t} \\
+\lambda_{3} \text { distortion }^{*} \text { structure }+X_{i t} T+\alpha_{i}+\varepsilon_{i t}
\end{gathered}
$$

...where structure $_{i, t}$ represents the industrial structure upgrading. We add the interaction of factor price distortion and industrial structure upgrading. The meanings of other variables are consistent with the baseline regression model.

We used the input and output indicators to evaluate industrial environmental efficiency using the super-SBM method considering the undesirable outputs. Factor price distortion is calculated using transcendental logarithmic production function based on Eq. (1)-(6). According to the previous literature, economic development, urbanization, foreign direct investment, R\&D, import and export are selected as control variables. Per capita GDP captures regional economic development, which is expressed as pgdp. Urbanization is measure by the ratio of urban population to total populations, which is expressed as urban. R\&D is evaluated by the ratio of R\&D investment to GDP, open is represented as the ratio of import and export to GDP, and fdi is evaluated by the ratio of FDI to GDP.

\section{Data Source and Descriptive Statistics}

All the data are from the China Environmental Yearbook, China Statistical Yearbook, and China Environmental Statistics Yearbook. Marketization index is collected from the China Province Marketization Index report. The objects of this study are 29 provinces during the period of 2007-2015 in China (excluding Tibet and Hainan due to lack of data). The descriptive statistics are displayed in Table 1.

\section{Empirical Analysis}

The Preliminary Analysis Based on the Different Model

This study makes a preliminary analysis of the static panel data, and observes the influence of independent variables in order to provide reference for baseline analysis. Subsequently, according to the results of the Hausman test, the random effect model or the fixed effect model are determined. Table 2 displays the regression results based on different models.

According to Table 2, we observe that the effect of factor price distortion is significantly negative in the

Table 2. Comparison of regression results based on different models.

\begin{tabular}{|c|c|c|c|c|c|c|}
\hline & OLS & OLS & RE & RE & FE & FE \\
\hline Distortion & $\begin{array}{c}-0.0554^{* * *} \\
(-4.60)\end{array}$ & $\begin{array}{c}-0.0686^{* * *} \\
(-6.17)\end{array}$ & $\begin{array}{c}-0.0515^{* * *} \\
(-5.10)\end{array}$ & $\begin{array}{c}-0.0539 * * * \\
(-5.41)\end{array}$ & $\begin{array}{c}-0.0521 * * * \\
(-4.93)\end{array}$ & $\begin{array}{c}-0.0522^{* * *} \\
(-4.86)\end{array}$ \\
\hline Control variables & $\mathrm{N}$ & $\mathrm{Y}$ & $\mathrm{N}$ & $\mathrm{Y}$ & $\mathrm{N}$ & $\mathrm{Y}$ \\
\hline Constant & $\begin{array}{c}0.6276^{* * *} \\
(19.08)\end{array}$ & $\begin{array}{c}-0.5768^{*} \\
(-1.66)\end{array}$ & $\begin{array}{c}0.4594 * * * \\
(10.63)\end{array}$ & $\begin{array}{c}-0.6677 \\
(-0.69)\end{array}$ & $\begin{array}{c}0.4610^{* * *} \\
(3.55)\end{array}$ & $\begin{array}{c}-0.4160 \\
(-0.34)\end{array}$ \\
\hline Sample size & 261 & 261 & 261 & 261 & 261 & 261 \\
\hline R2 & 0.4844 & 0.4800 & 0.4226 & 0.4594 & 0.4226 & 0.4623 \\
\hline
\end{tabular}

Note: $*$ indicates significance at the $10 \%$ level; ** indicates significance at the $5 \%$ level; *** indicates significance at the $1 \%$ level. 
OLS model. We also find that factor price distortion inhibits industrial environmental efficiency at the $1 \%$ level in the random effect model and fixed effect model. These empirical results are in line with expectations. According to the results of Hausmann test, the fixed effect model is more effective than the random effect model. Therefore, this study uses the fixed effect model to analyze the relationship between factor price distortion and industrial environmental efficiency.

\section{Baseline Regression Analysis Based on the Two-Way Fixed Effects Model}

Table 3 further presents the empirical results of the effect of factor price distortion on industrial environmental efficiency based on the two-way fixed effects model. We find that the estimation coefficient of factor price distortion is negative and statistically significant without control variables in model (1). Subsequently, we gradually add control variables and report the empirical results. We observe that the negative effect of factor price distortion is still significant in model (6). The results imply that the factor price distortions significantly hinder the improvement of industrial environmental efficiency. Factor price distortion increases by $1 \%$, resulting in a $5.22 \%$ reduction in efficiency in model (6).

According to the empirical results, we claim that the factor price distortion inhibits the improvement of industrial environmental efficiency. We explain the empirical result from the following aspects. Factor price distortion caused by imperfect market and government intervention reduces resource allocation efficiency. Factor price distortion reduces production costs, stimulates production activities [6], increases resource consumption, and reduces the willingness of enterprises to make technological progress. Distortion of factor price leads to a large flow of resources to heavily polluted and energy-intensive industries. In addition, factor price distortion leads to rent-seeking behavior. Enterprises with high production efficiency fail to get the normal cost of factor allocation. Enterprises with political connections but low productivity can use low factor costs to produce. Misallocation of factors results in waste of resources and loss of environmental efficiency. Low factor price allows inefficient industrial enterprises to continue production and increase pollution emissions. All these indirectly lead to the reduction of industrial environmental efficiency.

\section{Analysis of the Interaction between Factor Price Distortion and Industrial Structure Upgrading}

We further analyze the interaction between factor price distortion and industrial structure upgrading on industrial environmental efficiency. Table 4 reports the empirical result. We find that the coefficient of factor price distortion is significantly negative, which is consistent with baseline regression. The effect of industrial structure upgrading on industrial environmental efficiency is positive and statistically significant, which indicates that industrial structure upgrading significantly promotes the improvement of industrial environmental efficiency. We pay attention

Table 3. Results of factor price distortion on industrial environmental efficiency based on the two-way fixed effects model.

\begin{tabular}{|c|c|c|c|c|c|c|}
\hline & Model (1) & Model (2) & Model (3) & Model (4) & Model (5) & Model (6) \\
\hline Distortion & $\begin{array}{c}-0.0521 * * * \\
(-4.93)\end{array}$ & $\begin{array}{c}-0.0495 * * * \\
(-5.47)\end{array}$ & $\begin{array}{c}-0.0483 * * * \\
(-4.47)\end{array}$ & $\begin{array}{c}-0.0533 * * * \\
(-4.96)\end{array}$ & $\begin{array}{c}-0.0523 * * * \\
(-4.87)\end{array}$ & $\begin{array}{c}-0.0522 * * * \\
(-4.86)\end{array}$ \\
\hline Pgdp & & $\begin{array}{l}0.1136 \\
(1.17)\end{array}$ & $\begin{array}{c}0.2359 * * \\
(1.93)\end{array}$ & $\begin{array}{c}0.2603 * * \\
(2.17)\end{array}$ & $\begin{array}{c}0.1539 \\
(1.13)\end{array}$ & $\begin{array}{l}0.1559 \\
(1.15)\end{array}$ \\
\hline Urbanization & & & $\begin{array}{c}-1.0582 \\
(-1.64)\end{array}$ & $\begin{array}{c}-1.1333 * \\
(-1.78)\end{array}$ & $\begin{array}{c}-1.0016 \\
(-1.57)\end{array}$ & $\begin{array}{c}-0.9618 \\
(-1.48)\end{array}$ \\
\hline Fdi & & & & $\begin{array}{c}-0.2410 * * * \\
(-2.99)\end{array}$ & $\begin{array}{c}-0.2285 * * * \\
(-2.83)\end{array}$ & $\begin{array}{c}-0.2276^{* * *} \\
(-2.81)\end{array}$ \\
\hline $\mathrm{R} \& \mathrm{~d}$ & & & & & $\begin{array}{c}-0.8676 \\
(-1.67)\end{array}$ & $\begin{array}{c}-0.8998 \\
(-1.70)\end{array}$ \\
\hline Open & & & & & & $\begin{array}{c}-0.0259 \\
(-0.34)\end{array}$ \\
\hline Constant & $\begin{array}{c}0.4610^{* * *} \\
(3.55)\end{array}$ & $\begin{array}{c}-0.6677 \\
(-0.69) \\
\end{array}$ & $\begin{array}{c}-1.3698 \\
(-1.30)\end{array}$ & $\begin{array}{l}-1.4767 \\
(-1.43) \\
\end{array}$ & $\begin{array}{c}-0.3937 \\
(-0.32)\end{array}$ & $\begin{array}{c}-0.4160 \\
(-0.34) \\
\end{array}$ \\
\hline Sample size & 261 & 261 & 261 & 261 & 261 & 261 \\
\hline $\mathrm{R} 2$ & 0.4226 & 0.4262 & 0.4330 & 0.4551 & 0.4620 & 0.4623 \\
\hline Time Fixed Effect & $\mathrm{Y}$ & $\mathrm{Y}$ & $\mathrm{Y}$ & $\mathrm{Y}$ & $\mathrm{Y}$ & $\mathrm{Y}$ \\
\hline Regional Fixed Effect & Y & $\mathrm{Y}$ & Y & Y & Y & $\mathrm{Y}$ \\
\hline
\end{tabular}

Note: * indicates significance at the $10 \%$ level; ** indicates significance at the $5 \%$ level; *** indicates significance at the $1 \%$ level. 
Table 4. Results of the interaction between factor price distortion and industrial structure upgrading.

\begin{tabular}{|c|c|c|c|c|c|c|}
\hline & Model (1) & Model (2) & Model (3) & Model (4) & Model (5) & Model (6) \\
\hline Distortion & $\begin{array}{c}-0.0286^{* *} \\
(-2.05)\end{array}$ & $\begin{array}{c}-0.0286^{* * *} \\
(-2.05)\end{array}$ & $\begin{array}{c}-0.0283^{* *} \\
(-2.02)\end{array}$ & $\begin{array}{c}-0.0326^{* *} \\
(-2.37)\end{array}$ & $\begin{array}{c}-0.0303^{* *} \\
(-2.22)\end{array}$ & $\begin{array}{c}-0.0303^{* *} \\
(-2.21)\end{array}$ \\
\hline Distortion* structural upgrading & $\begin{array}{c}-0.0236^{* *} \\
(-1.98)\end{array}$ & $\begin{array}{c}-0.0237 * * \\
(-1.98)\end{array}$ & $\begin{array}{c}-0.0238^{* *} \\
(-1.99)\end{array}$ & $\begin{array}{c}-0.0248^{* *} \\
(-2.11)\end{array}$ & $\begin{array}{c}-0.0253^{* *} \\
(-2.17)\end{array}$ & $\begin{array}{c}-0.0254 * * \\
(-2.17)\end{array}$ \\
\hline Structural upgrading & $\begin{array}{c}0.1894^{* * * *} \\
(3.04)\end{array}$ & $\begin{array}{c}0.1929 * * * \\
(2.78)\end{array}$ & $\begin{array}{c}0.1718^{* *} \\
(2.38)\end{array}$ & $\begin{array}{c}0.1905^{* * *} \\
(2.68)\end{array}$ & $\begin{array}{c}0.2248^{* * *} \\
(3.12)\end{array}$ & $\begin{array}{c}0.2258^{* * *} \\
(3.10)\end{array}$ \\
\hline Pgdp & & $\begin{array}{c}-0.0121 \\
(-0.11) \\
\end{array}$ & $\begin{array}{c}0.0815 \\
(0.58) \\
\end{array}$ & $\begin{array}{c}0.0898 \\
(0.66) \\
\end{array}$ & $\begin{array}{r}-0.0890 \\
(-0.57) \\
\end{array}$ & $\begin{array}{c}-0.0907 \\
(-0.57) \\
\end{array}$ \\
\hline Urbanization & & & $\begin{array}{c}-0.6861 \\
(-1.03)\end{array}$ & $\begin{array}{c}-0.7193 \\
(-1.10)\end{array}$ & $\begin{array}{c}-0.4456 \\
(-0.68)\end{array}$ & $\begin{array}{c}-0.4543 \\
(-0.68)\end{array}$ \\
\hline Fdi & & & & $\begin{array}{c}-0.2589 * * * \\
(-3.25)\end{array}$ & $\begin{array}{c}-0.2449 * * * \\
(-3.09)\end{array}$ & $\begin{array}{c}-0.2452^{* * * *} \\
(-3.09)\end{array}$ \\
\hline$R \& d$ & & & & & $\begin{array}{c}-1.1802 * * \\
(-2.26) \\
\end{array}$ & $\begin{array}{c}-1.1724 * * \\
(-2.22) \\
\end{array}$ \\
\hline Open & & & & & & $\begin{array}{l}0.0075 \\
(0.10)\end{array}$ \\
\hline Constant & $\begin{array}{c}0.2307 * * * \\
(2.62)\end{array}$ & $\begin{array}{c}0.3471 \\
(0.34)\end{array}$ & $\begin{array}{c}-0.2228 \\
(-0.19)\end{array}$ & $\begin{array}{c}-0.2060 \\
(-0.18)\end{array}$ & $\begin{array}{l}1.5151 \\
(1.12)\end{array}$ & $\begin{array}{l}1.5308 \\
(1.12)\end{array}$ \\
\hline Sample size & 261 & 261 & 261 & 261 & 261 & 261 \\
\hline $\mathrm{R} 2$ & 0.4491 & 0.4491 & 0.4518 & 0.4771 & 0.4892 & 0.4892 \\
\hline Time Fixed Effect & Y & Y & Y & Y & Y & Y \\
\hline Regional Fixed Effect & $\mathrm{Y}$ & $\mathrm{Y}$ & $\mathrm{Y}$ & $\mathrm{Y}$ & $\mathrm{Y}$ & Y \\
\hline
\end{tabular}

Note: * indicates significance at the $10 \%$ level; ** indicates significance at the $5 \%$ level; *** indicates significance at the $1 \%$ level.

to the effect of the interaction between factor price distortion and industrial structure upgrading. We observe that the coefficient of interaction between factor price distortion and industrial structure upgrading is significantly negative in model (1), which indicates that the negative impact of factor price distortion is stronger in regions with low-level industrial structure. Subsequently, we gradually add control variables and report the empirical results and find that there is no significant change. Therefore, the inhibiting impact of factor price distortion on industrial environmental efficiency has been improved through the upgrading of industrial structure.

The upgrading of industrial structure promotes the gradual transfer of factors to high-tech sectors. The upgrading of industrial structure increases $R \& D$ investment, realizes technological upgrading, and improves the quality of industrial development, which promotes the redistribution and flow of factors, makes the factors flow to more efficient departments, reduces pollutant emissions and improves environmental quality.

Factor price distortion makes low-level industries with high energy consumption and slow advancement of technology in China still profitable, which makes the transformation and upgrading of industries fall into a dilemma. It is difficult for backward industrial structures to achieve high economic output with low resource consumption. Upgrading industrial structure influences efficiency through factor allocation, which stems from the flow and allocation of factors (such as capital, labor, and energy) among the sectors [46]. Therefore, factor price distortion hinders the upgrading of industrial structure, thus inhibiting industrial environmental efficiency. The inhibitory effect of factor price distortion is stronger in areas with slow upgrading of industrial structure.

\section{Heterogeneity Test}

In order to further clarify the differences of industrial environmental efficiency among regions, the eastern region, the central region and western region are discussed based on China Statistical Yearbook. This study examines the non-linear relationship between factor price distortions and industrial environmental efficiency. Table 5 reports the results in different regions. We observe that the estimation coefficient of factor price distortion is not significant in the eastern region. Models (2) and (3) indicate that the estimation coefficient of factor price distortion is significantly negative in central and western regions. These results show that the inhibiting effect of factor price distortion is more significant in the central and western regions. 
Table 5. Results of heterogeneity test in different regions.

\begin{tabular}{|c|c|c|c|}
\hline & Model (1) & Model (2) & Model (3) \\
\hline & East region & Central region & West region \\
\hline Distortion & $\begin{array}{c}-0.0296 \\
(-1.54)\end{array}$ & $\begin{array}{c}-0.0694 * * * \\
(-5.22)\end{array}$ & $\begin{array}{c}-0.0761 * * * \\
(-5.47)\end{array}$ \\
\hline Control variables & $\mathrm{Y}$ & $\mathrm{Y}$ & $\mathrm{Y}$ \\
\hline Constant & $\begin{array}{c}-2.3774 \\
(0.67)\end{array}$ & $\begin{array}{c}0.5397 * * * \\
(11.93)\end{array}$ & $\begin{array}{l}1.7005 \\
(1.14)\end{array}$ \\
\hline Sample number & 90 & 54 & 117 \\
\hline $\mathrm{R} 2$ & 0.4405 & 0.5247 & 0.5690 \\
\hline Time Fixed Effect & $\mathrm{Y}$ & $\mathrm{Y}$ & Y \\
\hline Regional Fixed Effect & Y & Y & Y \\
\hline
\end{tabular}

Note: * indicates significance at the $10 \%$ level; ** indicates significance at the $5 \%$ level; *** indicates significance at the $1 \%$ level.

Table 6. Robustness test using the system GMM.

\begin{tabular}{|c|c|c|}
\hline & Model (1) & Model (2) \\
\hline Distortion & $\begin{array}{c}-0.0410 * * * \\
(-3.56)\end{array}$ & $\begin{array}{c}-0.0614 * * * \\
(-4.69)\end{array}$ \\
\hline Control variables & $\mathrm{N}$ & Y \\
\hline Efficiency $_{\mathrm{t}-1}$ & $\begin{array}{c}-0.3193 * * * \\
(-6.84)\end{array}$ & $\begin{array}{c}-0.3125^{* * *} \\
(-6.49)\end{array}$ \\
\hline Constant & $\begin{array}{c}0.7758^{* * *} \\
(23.55)\end{array}$ & $\begin{array}{c}1.3106^{* * *} \\
(2.78)\end{array}$ \\
\hline Sample size & 232 & 232 \\
\hline $\operatorname{AR}(1)$ & 0.0570 & 0.0160 \\
\hline $\operatorname{AR}(2)$ & 0.4837 & 0.2351 \\
\hline Sargan Value & 21.766 & 20.813 \\
\hline \multicolumn{3}{|c|}{$\begin{array}{l}\text { Note: } * \text { indicates significance at the } 10 \% \text { level; } * * \text { indicates } \\
\text { significance at the } 5 \% \text { level; } * * * \text { indicates significance at the } \\
1 \% \text { level. }\end{array}$} \\
\hline
\end{tabular}

\section{Robustness Test}

We use the alternative regression model to test robustness. The system generalized method of moments (GMM) estimator is selected, which helps to control for simultaneous and endogeneity problems. We regard all regression variables as endogenous regression variables in the model, and test them by using their lag level in differential equations and their lag differences in horizontal equations. Table 6 presents the results based on the system GMM method. We find that the coefficients of the factor price distortion are significantly negative, indicating that the estimation results are consistent with the baseline results. Therefore, we believe that the result of factor price distortion hindering industrial environmental efficiency is robust.

\section{Conclusions}

The government uses administrative monopoly power to intervene in the pricing mechanism of the factor market, resulting in factor price distortion. This study identifies the relationship between factor price distortion and industrial environmental efficiency using the fixed effect model. Meanwhile, we also examine the influence mechanism of industrial structure upgrading on factor price distortion affecting industrial environmental efficiency. The results show that factor price distortion significantly inhibits industrial environmental efficiency. Moreover, the inhibitory effect of factor price distortion is weakened in areas with better upgrading of industrial structure. Further investigation of the heterogeneity effect shows that the inhibitory impact of factor price distortion is more significant in central and western regions.

Compared with the product market, the factor market plays a fundamental role in improving economic development. We should improve the negative impacts of factor price distortion on the misallocation of resources and industrial structure. The government should actively promote the marketization process of the factor market and reduce market intervention. Local governments should eliminate market segmentation and regional barriers to form a unified national market to the allocation of production factors.

Our research shows that upgrading industrial structure improves industrial environmental efficiency. The government should encourage the development of environmental protection sectors and high-tech industries, reduce environmental damage in energyintensive and pollutant-intensive industries, increase the investment in technological innovation and phase out backward industrial enterprises and improve the transfer of industrial structure.

The government should increase policy support for industrial cleaner production, energy conservation and emission reduction, provide financial, technological and 
human resources support for resource conservation, encourage the elimination of backward technologies, and strengthen environmental regulation in order to reduce pollution emission and promote environmental efficiency.

\section{Conflict of Interest}

The authors declare no conflict of interest.

\section{References}

1. CHEN S. Energy consumption, carbon dioxide emission and sustainable development of China's industry. Economics Research Journal, 4, 41, 2009 [In Chinese].

2. SUN X., ZHOU X., CHEN Z., YANG Y. Environmental efficiency of electric power industry, market segmentation and technological innovation: Empirical evidence from China. Science of the Total Environment, 2019. In Press.

3. YANG X., FENG K., SU B., ZHANG W., HUANG S. Environmental efficiency and equality embodied in China's inter-regional trade. Science of the Total Environment, 672, 150, 2019.

4. BI G.B., SONG W., ZHOU P., LIANG L. Does environmental regulation affect energy efficiency in China's thermal power generation? Empirical evidence from a slacks-based DEA model. Energy Policy, 66, 537, 2014.

5. SEKER F., ERTUGRUL H.M., CETIN M. The impact of foreign direct investment on environmental quality: A bounds testing and causality analysis for Turkey. Renewable and Sustainable Energy Reviews, 52, 347, 2015.

6. KOUNETAS K. Heterogeneous technologies, strategic groups and environmental efficiency technology gaps for European countries. Energy Policy, 83, 277, 2015.

7. YIN J., WANG S., GONG L. The effects of factor market distortion and technical innovation on China's electricity consumption. Journal of Cleaner Production, 188, 195, 2018.

8. YANG M., YANG F., SUN C. Factor market distortion correction, resource reallocation and potential productivity gains: An empirical study on China's heavy industry sector. Energy Economics, 69, 270, 2018.

9. BRANDT L., TOMBE T., ZHU X. Factor market distortions across time, space, and sectors in China. Review of Economic Dynamics, 16 (1), 39, 2013.

10. LIN B., CHEN Z. Does factor market distortion inhibit the green total factor productivity in China? Journal of Cleaner Production, 197, 25, 2018.

11. CHEN K.H., YANG H.Y., LEE J.M., CHI C.F. The impact of energy prices on energy consumption and energy efficiency: evidence from Taiwan. Energy Efficiency, 9 (6), 1329, 2016.

12. HUANG Y.P., TAO K.Y. Causes of and remedies for the people's republic of China's external imbalances: the role of factor market distortion. Ssrn Electronic Journal, 6, 7, 2011.

13. ZHANG J., ZHOU X.Y., LI Y. Does factor market distortion barrage Chinese firms' R\&D? Economics Research Journal, 8, 78, 2011 [In Chinese].
14. ZHOU L.A. Governing China's local officials: an analysis of promotion tournament model. Economics Research Journal, 7, 36, 2007 [In Chinese].

15. DAI X., CHENG L. Market distortions and aggregate productivity: evidence from Chinese energy enterprises. Energy Policy, 95, 304, 2016.

16. OUYANG X., SUN C. Energy savings potential in China's industrial sector: From the perspectives of factor price distortion and allocative inefficiency. Energy Economics, 48, 117, 2015.

17. WEI C., LI C.Z. Resource misallocation in Chinese manufacturing enterprises: evidence from firm-level data. Journal of Cleaner Production, 142, 837, 2017.

18. WANG H., MIAO Z., WANG S.Q. Spatial spillover, industrial agglomeration effect and industrial green innovation efficiency. Forum on Science and Technology in China, 12, 33, 2015.

19. CLAUDIA K., TRUONG T. Impact assessment of emissions stabilization scenarios with and without induced technological change. Energy Policy, 35 (11), 5337, 2007.

20. AMORE M.D., CÉDRIC S., ALMINAS Z. Credit supply and corporate innovation. Journal of Financial Economics, 109 (3), 835, 2013.

21. HSU P.H., XUAN T., YAN X. Financial development and innovation: Cross-country evidence, Journal of Financial Economics, 112 (1), 116, 2014.

22. BARTELSMAN E., HALTIWANGER J., SCARPETTA S. Cross-country differences in productivity: The role of allocation and selection. American Economic Review, 103 (1), 305, 2013.

23. FAN Y., LIAO H., WEI Y.M. Can market oriented economic reforms contribute to energy efficiency improvement? Evidence from China. Energy Policy, 35 (4). 2287, 2007

24. POPP D. Induced innovation and energy prices. American Economic Review, 92 (1), 160, 2002.

25. GROSSMAN G., KRUEGER A. Economic growth and the environment. The Quarterly Journal of Economics, 110, $353,1995$.

26. COLE M.A., ELLIOTT R.J.R., SHANSHAN W.U. Industrial activity and the environment in China: An industry-level analysis. China Economic Review, 19 (3), 393, 2008.

27. TALUKDAR D., MEISNER C.M. Does the private sector help or hurt the environment? Evidence from carbon dioxide pollution in developing countries. World Development, 29 (5), 827, 2001.

28. LI W., WANG W., WANG Y., QIN Y. Industrial structure, technological progress and $\mathrm{CO}_{2}$ emissions in China: Analysis based on the STIRPAT framework. Natural Hazards, 88, 1545, 2017.

29. HAO Y., LIAO H., WEI Y.M. Is China's carbon reduction target allocation reasonable? An analysis based on carbon intensity convergence. Applied Energy, 142, 229, 2015.

30. XU G., JIANG Z. The relationship among technical progress, structural change, and energy efficiency in the United States. Science of Science and Management of S.\& T. 28 (3), 104, 2007 [In Chinese].

31. SHI D. The improvement in energy efficiency in China's economic growth. Economics Research Journal, 9, 49, 2002.

32. ZHOU X.Y., ZHANG J., LI J.P. Industrial structural transformation and carbon dioxide emissions in China. Energy Policy, 57 (6), 43, 2013. 
33. CHENG Z., LI L., LIU J. Industrial structure, technical progress and carbon intensity in China's provinces. Renewable and Sustainable Energy Reviews, 81, 2935, 2018.

34. FAN S., ZHANG X., ROBINSON S. Structural change and economic growth in China. Review of Development Economics, 7 (3), 360, 2003.

35. SCHAFER A. Structural change in energy use. Energy Policy, 33 (4), 429, 2005.

36. ZHOU X., LEI K., MENG W., KHU S. Industrial structural upgrading and spatial optimization based on water environment carrying capacity. Journal of Cleaner Production, 165, 1462, 2017.

37. LIN Y. Eliminating market distortion. Capital Market, 5, 12, 2014 [In Chinese].

38. LIN B.Q., DU K.R. The energy effect of factor market distortion in China.Economics Research Journal, 9, 125, 2013.

39. LAU L.J., YOTOPOULOS P.A. A test for relative efficiency and application to Indian agriculture. American Economic Review, 61 (1), 94, 1971.

40. ATKINSON S.E., HALVORSEN R. Parametric efficiency tests, economies of scale, and input demand in U.S. electric power generation. International Economic Review, 25 (3), 647, 1984.

41. YANG X., LI C. Industrial environmental efficiency, foreign direct investment and export - Evidence from 30 provinces in China. Journal of Cleaner Production, 212, 1490, 2019.

42. GÓMEZ-CALVET R., CONESA D., GÓMEZ-CALVET A.R., TORTOSA-AUSINA E. Energy efficiency in the European Union: what can be learned from the joint application of directional distance functions and slacksbased measures. Applied Energy, 132, 137, 2014.

43. TONE K. A slacks-based measure of efficiency in data envelopment analysis. European Journal of Operational Research, 130, 498, 2001.

44. CHARNES A., COOPER W.W. Programming with linear fractional functionals. Naval Research Logistics, 9, 181, 1963.

45. LI C., YUAN B., ZHANG Y. Effect assessment of ecological construction in china from 2008 to 2014. Polish Journal of Environmental Studies. 28, 1, 2019.

46. LI K., LIN B. Economic growth model, structural transformation, and green productivity in China. Applied Energy, 187, 489, 2017. 